\title{
Cretaceous-lower Paleogene ostracods from the Pelotas Basin, Brazil
}

\section{CEOLIN ${ }^{1}$}

Cretaceous and Cretaceous/Paleogene marine ostracod assemblages from the Pelotas Basin and their paleoecology are studied. A total of 479 cutting samples from five wells were analized. Ninety-eight specimens belonging to 9 families, 21 genera and 34 species were recovered. The most representative Cretaceous species are: Cytherella cf. C. araucana Bertels, Cytherelloidea spirocostata Bertels, Bairdoppilata triangulata Edwards, Actinocythereis indigena Bertels, Brachycythere gr. sapucariensis Krömmelbein, Wichmannella araucana Bertels and Wichmannella meridionalis Bertels. The Turonian was the most ostracod-rich interval with significant presence of the genera Brachycythere and Cytherella. The CretaceousPaleogene boundary is marked by a faunal change with the local disappearance of the genera Cytherelloidea, Argilloecia, Cythereis, Brachycythere, Majungaella, Pondoina and Rostrocytheridea, and the first local occurrence of Neonesidea, Bairdoppilata, Ambocythere, Buntonia, Langiella?, Trachyleberis and Krithe. The Cretaceous ostracod associations in the Pelotas Basin suggest a neritic marine environment with warm water. 